\title{
The Mandatory Handshake in Danish Naturalisation Procedures: A Critical Race Studies Perspective
}

\author{
Anika Seemann ${ }^{1}$ \\ Max Planck Institute for Social Law and Social Policy, Munich, Germany
}

This article examines the recent introduction of a mandatory handshake in Danish naturalisation procedures from the perspectives of 'racism' and 'race discrimination'. Drawing upon Critical Race Theory, it employs a discursive, deconstructive and contextual analysis to uncover the racist underpinnings and effects of the handshake requirement. The article is divided into two main parts. Part I demonstrates why the handshake requirement needs to be understood as racism. The analysis focuses on three aspects of the handshake requirement: 1) the 'racializing narratives' drawn upon in the legislative process; 2) the motivations behind the legislation; and 3) the ways in which the handshake requirement manifests as racism in society. Part II assesses the relevance of this finding from the perspective of anti-discrimination law. It examines the discriminatory nature of the handshake, before discussing some of the shortcomings of current international and European law in relation to race discrimination. The article closes by discussing the importance of developing a more 'race-aware' approach to the law in European legal scholarship.

Keywords: racism, racialization, discrimination, Islamophobia, citizenship

\section{Introduction ${ }^{2}$}

On 1 January 2019, it became a legal requirement for obtaining Danish citizenship by way of naturalisation that one shake hands with an official during a citizenship ceremony. In taking this step, Denmark was the first country in the world to make a handshake a formal requirement for

\footnotetext{
${ }^{1}$ Corresponding author. Address: Anika Seemann, Max-Planck-Institut für Sozialrecht und Sozialpolitik, Amalienstraße 33, D-80799 München, Germany. Email: seemann@mpisoc.mpg.de

2 The author would like to thank Mathias Möschel and Jihan Kahssay as well as the editors and anonymous reviewers of this journal for their very helpful comments on earlier versions of this article.
} 
naturalisation. In the context of citizenship and immigration, however, the act of shaking hands has been politically controversial across Europe for some time (see e.g. Hertogh, 2009). In 2018, Switzerland and France both denied individuals naturalisation based on their refusal to shake hands with officials (O'Grady 2018; Breeden 2018). While several religions, including Judaism, have rules with regard to shaking hands with members of the opposite sex, public and political discourse across Europe has in recent years revolved almost exclusively around instances involving Muslims. In this political discourse, a refusal to shake hands is often presented as opposition to 'Western' culture, a lack of 'integration' and a disregard for 'gender equality'. Consequently, legal, administrative and judicial measures concerning handshakes are typically justified on the basis of requirements for 'integration' and respect for 'gender equality'.

This article examines the Danish handshake requirement from the perspectives of 'racism' and 'race discrimination'. It investigates whether the handshake requirement amounts to racism against Muslims and what legal remedies may be available against it under anti-discrimination law. It draws in particular upon approaches developed by Critical Race Theory (CRT) (Crenshaw 1995; Delgado and Stefancic 2017). CRT emerged in American legal theory in the 1980s as a critique of the US Supreme Court's 'colourblind' approach to the law. Its main criticism was and remains that formally neutral readings of the law can reinforce existing racisms in society. CRT is interdisciplinary, and draws inter alia upon liberalism, feminism, critical legal theory, Marxism, poststructuralism and pragmatism (Möschel 2014, 41). In order to point towards the ways in which the law helps to uphold racist social structures, it incorporates historical, sociological and political context into its analysis. Its basic premise is that racism is endemic to Western societies. The role of CRT, therefore, is to confront 'law's complicity in the violent perpetuation of a racially defined economic and social order' (Douzinas and Gearey 2005, in: Möschel 2014, 114).

As follows from the above, CRT challenges authority and is critical in its engagement with the law. It holds that legal doctrine must not be the start and end point of legal scholarly engagement with race. Instead, the law is approached by way of discursive, deconstructive and contextual analyses. This allows a CRT-based analysis to move beyond an 'inside' perspective of the law and to uncover racisms inherent in the law that doctrinal interpretations may overlook. Methodologically, the discursive element of 
the analysis involves investigating how the law draws upon and contributes to racist and racializing narratives. A deconstructive reading of the law, in turn, refers to the critical challenging of arguments presented in legal sources to uncover their underlying (potentially racist) meaning and intent. Finally, the contextual element of the analysis involves placing the law in its historical and socio-political context in order to understand how it interacts with racerelated social norms. This threefold approach is ideally suited to uncovering the complex relationship between law and racism, and will therefore be the guiding method of this article. In order to analyse the potential racism inherent in the handshake requirement, the article draws upon concepts of racism from sociology, philosophy and political theory, before discussing possible remedies under anti-discrimination law. This is in line with CRT's interdisciplinary starting point, in which concepts from the social sciences and humanities are incorporated into an analysis of the law.

The article is divided into two main parts. The aim of Part I is to analyse the handshake requirement in relation to the concepts of 'racism' and 'racialization'. After a critical examination of these two concepts, the main focus of Part $I$ is on demonstrating how the handshake requirement can be understood as racism. In doing so, the analysis focuses on three aspects of the handshake requirement: 1) the 'racial narratives' drawn upon in the legislative process; 2) whether there was a racist intent on the part of the legislator; 3) the ways in which the handshake requirement manifests as racism when seen in its socio-political context. Part I concludes that the handshake requirement must be understood as informed by and contributing to anti-Muslim racism. Part II assesses the relevance of this finding from the perspective of discrimination law. It examines, first, in what ways the handshake requirement may be seen as discriminatory, before discussing some of the shortcomings in current international and European human rights law in relation to race discrimination. The article closes by discussing the importance of developing a more 'race-aware' and critical approach to the law in European legal scholarship.

The article aims to make a modest contribution to the development of a European CRT movement. Despite important recent scholarly contributions to the field (Möschel 2014; Barskanmaz 2019), 'race' remains a widely overlooked analytical category in European legal scholarship. In much of continental Europe, race is to this day understood as the 'classical' biological racism that evokes associations with bygone eras (colonialism or the 
Holocaust), or it is seen as a concept that is relevant only to other parts of the world (mainly the United States). Due to what Möschel terms 'Continental European Colourblindness' $(2014,110)$, which refers to a failure to acknowledge that race still matters in Europe, law that is informed by or manifests as racism is rarely debated in relation to the concepts of 'racism' or 'race discrimination' in European public and scholarly discourses. Instead, they tend to be discussed in the context of personal autonomy, freedom of religion and the wider interests of democratic societies. While these are important dimensions, this article seeks to highlight why a more race-aware approach to the law is needed in Europe.

\section{Part I: The Handshake Requirement as Racism}

\section{The Handshake Requirement}

Danish naturalisation procedures differ from procedures in most other countries. An individual becomes a Danish citizen not based on an administrative act, but by statute. The basis for this is $\S 44$ of the Danish constitution, which stipulates that 'no alien shall be naturalised except by statute' (Folketinget 2013). The background to this provision, which has formed part of the Danish constitution since its adoption in 1849, was to assign the powers to grant naturalisation to the legislator, instead of the monarch, who had decided such matters until then (Ersbøll 2008, 591). However, while the legislator in principle could assess each individual case, it became custom during the twentieth century that this was not done. An individual included in a 'naturalisation bill' can therefore be reasonably certain of acquiring citizenship. The act of law may, however, stipulate that there are further conditions the individual needs to meet before naturalisation can take place. This typically involves rescinding another citizenship.

Since 1 January 2019, a handshake has been another such condition to be met in order for individuals listed on a naturalisation bill to acquire Danish citizenship. On 20 December 2018, the Danish parliament passed a law that granted the responsible Minister the authority to lay down detailed rules on the organisation and conduct of mandatory citizenship ceremonies in naturalisation procedures. ${ }^{3}$ Fifty-five MPs voted in favour of the bill, twenty-

\footnotetext{
${ }^{3} \S 10$ Section 4, Lov om dansk indfødsret [Act on Naturalisation], as added by Lov nr 1735 af 27/12/2018 om ændring af lov om dansk indfødsret og lov om danskuddannelse til voksne udlændinge m.fl.
} 
three against, and thirty abstained. ${ }^{4}$ The law itself does not contain an express provision on the handshake requirement. However, the Minister had made it clear that she intended to use the authority the law would grant her to make a handshake a formal element of citizenship ceremonies and thereby a condition for naturalisation. Because the handshake requirement was a central objective of the legislation, much of the government's explanatory note on the bill, as well as the debate that followed in parliament, revolved around the handshake requirement. On 27 December the law was promulgated and on the same day, the responsible Minister, in accordance with her new powers, issued regulations regarding the details of how citizenship ceremonies were to take place. ${ }^{5}$

The new provisions stipulate that within two years of being named in an act of law as qualifying for Danish citizenship, an individual has to partake in a ceremony in the municipality in which he or she is resident and there sign a pledge to abide by Danish laws and shake hands with at least one official. The Minister's regulation states the specific requirements for the handshake as follows:

one or more representatives of the local council [must] exchange a handshake with the applicant without a glove, palm of the hand against palm of the hand, to commemorate and specifically mark the moment in the applicant's life where he or she becomes a Danish citizen. ${ }^{6}$

Officials are instructed to inform applicants at the start of each ceremony that they will have to shake hands with one or more government representatives during the ceremony. ${ }^{7}$ Upon completion of the ceremony, the official has to send to the Ministry, without delay, a form confirming that the individual has taken part in the ceremony and shaken hands. ${ }^{8}$ The Ministry, in turn, confirms that all conditions for citizenship have been fulfilled. An individual legally becomes a citizen on the day he or she has successfully completed the citizenship ceremony. Without the official's confirmation that the individual

\footnotetext{
${ }^{4}$ Folketingstidende (FT), 2018-19 meeting, Supplement F, meeting 40, concerning L 80 (the change of Lov nr 1735 af 27/12/2018), vote number 196.

${ }^{5}$ Bekendtgørelse nr 1767 af 27/12/2018 om kommunalbestyrelsernes afholdelse af grundlovsceremonier.

${ }^{6} \S 8$, ibid.

${ }^{7} \S 5$, ibid.

$8 \S 9$, ibid.
} 
has shaken hands, the Ministry would decline to issue a certificate of citizenship to the applicant. ${ }^{9}$

\section{The Contested Concepts of (Cultural) Racism and Racialization}

What counts as 'racism', in particular in relation to 'religious groups' such as Muslims, is highly contested (Meer 2008, 2013; Gotanda 2011; Klug 2012; Siebers and Dennissen 2015; Lauwers 2019). The 'biological racism' of the past, often understood as a belief in the existence of human races, seems insufficient to adequately capture the structures of present-day racism against minorities. The concept of 'cultural racism' (or 'new racism') seeks to fill this seeming void. 'Cultural racism' refers to the (intentional or unintentional) ethnic stereotyping of a group based on cultural heritage, language, traditions and religion. It involves an assertion of a majority culture over a minority culture, based on a conviction that the minority culture is ultimately incompatible with that of the majority. The convictions underlying 'cultural racism' mean that 'culture can also function like a nature', so that cultural racism can manifest in the same way as biological racism (Taguieff 1990; Balibar 1991).

The use of the concept of cultural racism is highly contested, however. Some critics argue that cultural racism has little to do with 'race' as it was understood in the 'classical' biological racism of the nineteenth and twentieth centuries and that the term 'racism' is therefore unfitting. In this view, the concept of 'cultural racism' blurs the conceptual divide between racism and concepts such as xenophobia, which refers to a fundamental dislike of an 'Other'. Siebers and Dennissen for example argue that 'cultural fundamentalism' or 'cultural essentialism' would be better suited to capturing the processes often referred to as 'cultural racism'. By these concepts they refer to processes that 'frame migrants as cultural subjects, bearers of cultural characteristics that are assumedly incommensurable, incompatible or contradictory to assumed cultural traits of non-migrant citizens' (2015, 474; see also: Stolcke 1995). Others criticize the term from the opposite direction: they argue that 'cultural racism' cannot be meaningfully distinguished from 'biological racism'. Since biological races do not exist, racism has always been a social construct, and cultural and biological factors

\footnotetext{
${ }_{9}^{9}$ Folketingstidende (FT), 2018-19 meeting, Supplement A concerning L 80 (the change of Lov nr 1735 af 27/12/2018), pp. $4-5$.
} 
have intersected in historical manifestations of racism (Zakharov 2015; Lauwers 2019).

These objections to the concept of 'cultural racism' highlight the challenges of defining 'racism'. Once one has accepted that biological races do not exist, the concept of racism requires a clear definition that captures the complex social processes at play. Recognizing this difficulty, many scholars attempt to narrow the definition of (cultural) racism to those cases in which the cultural difference of a group is seen as 'innate, indelible, and unchangeable' (Fredrickson 2015, 5). The genuine prospect of assimilation - as believed by a cultural majority - therefore becomes a key criterion in the identification of racism. Only then can '(cultural) racism' be distinguished from the mere dislike of other ethnicities for example. This definition operates closely along the lines of a belief in a 'bloodline'. While 'markers' identifying an individual as belonging to a race do not have to be immediately visible (as they are also a social construct rather than a biological feature), racism is based on a belief in certain biological traits that are inherited and immutable. A further criterion proposed to identify racism is the establishment of 'hierarchy', as opposed to the wish for the mere 'spatial' separation of cultures advocated by xenophobes (Stolcke 1995, 8).

Such narrower definitions of racism have become increasingly established in theoretical discourses on racism (Lauwers 2019). They address the impossibility of distinguishing biological racism from cultural racism, and yet acknowledge that for the concept of 'racism' to be a meaningful analytical category, it has to be separated from concepts such as xenophobia. However, one of the main shortcomings of many definitions of racism is that they tend to operate on the basis of an individually or collectively held belief in the prospect of assimilation. This raises the question of how racism can be convincingly established. After all, most individuals and societies would categorically deny holding racist beliefs. There is also a risk that the focus in discourses on race remains on 'a psychological condition, an attitude, a prejudice - some event that occurs in the mind of an actor that predisposes the actor to take an action that is racist' rather than the structural manifestations of racism so typically found in Western societies (Nieminen 2019).

With these limitations in mind, the approach taken to racism in this article will be a structural one, drawing on the concept of 'racialization'. The concept of racialization refers to the 'extension of racial meaning' to a 'relationship, 
social practice or group' (Omi and Winant 2015, 111). It is important to point out that this leads to the formation of 'racialized groups' rather than 'races' (Hochman 2019, 1246). Racialization allows us to focus on the processes through which these 'racialized groups' are constructed, and the 'marginalizing practices and racialized social hierarchies' that tend to accompany such processes (Nieminen 2019,77). It acknowledges the ways in which social understandings of 'races' and 'racism' are established discursively and structurally in society and therefore allows us to move beyond questions of belief or intent. Another helpful concept for the purposes of this analysis is that of 'racial knowledge', which refers to the scientific and everyday construction of ideas of race in society (Goldberg 1993).

Racism, then, is understood here as an ideology that 'attaches negatively evaluated characteristics to a socially constructed group, membership of which is attributed based on the possession of certain markers and seen as unchangeable; assumes these characteristics to be innate to all group members; and uses these characteristics as a justification for social hierarchies, exclusion, hostility, or violence' (Lauwers 2019, 313). This definition can be classed as one of the aforementioned narrower categories, centred around the idea of a 'blood line' equivalent. But importantly, it allows us to draw upon the concept of racialization: racism is not limited to personal beliefs, but groups can be constructed as races. This racialization can in turn give rise to negative 'social, economic or political practices' (Lauwers, 2019, 309). This definition is valuable also because it does not overlap with 'cultural essentialism' or 'cultural fundamentalism', which refer primarily to a spatial differentiation of 'cultures'. Instead, it acknowledges that for there to be racism, there has to a type of social hierarchy.

The main task of the following section, then, is to assess against the background of this definition in what ways the handshake requirement can be understood as racism. This will be done by analysing the communicative processes through which anti-Muslim racism is referenced, constructed and manifested in the context of the handshake requirement. This requires us to look at the historical background of discourses surrounding the minority group concerned, the ways in which 'racial knowledge' is (re-)produced throughout the legislative process, the intentions of the legislator, as well as the socio-political context within which the handshake requirement operates. 


\section{Understanding the Handshake Requirement as Racism}

This section makes three central claims: a) the legislative process behind the handshake requirement is part of a process of racializing Muslims; b) the arguments put forward during the legislative process suggest that the handshake requirement is intended as racism; c) the handshake requirement manifests as racism in Danish society.

\section{The Racialization of Muslims}

Focusing first on the justifications for the handshake requirement, we can identify two interconnected arguments invoked during the legislative process: i) 'Danish values' are under threat due to Muslim immigration; ii) 'gender equality' is under threat due to Muslim immigration. Both of these are prominent narratives in Denmark that over the past decades have led to a racialization of Muslims. This is due to the ways in which these narratives have constructed Muslims as a group associated with innate negative characteristics.

In the explanatory note to the bill, the government defined the official objectives for introducing the mandatory handshake as follows:

Based on a basic Danish cultural norm, which in the opinion of the government the handshake expresses, the applicant will [by shaking hands] express the particular respect for Danish society, which, in the opinion of the government, should be associated with the act of being granted Danish citizenship. At the same time, he or she will symbolically signal that he or she has embraced Danish society and Danish values. ${ }^{10}$

The official argument for the measure was thus that citizenship applicants could signify that they had embraced 'Danish values'. In the government's view, a handshake is an expression of 'Danish values', more specifically the value of greeting others respectfully. Because of its particular cultural significance to the majority of Danish citizens, shaking hands with an official during a citizenship ceremony, then, is to signal that an individual has assimilated sufficiently into Danish society to be worthy of citizenship.

The idea of 'Danish values', alluding to a consensus-based, homogenous nation, has been a prominent theme throughout Danish history. From the late

\footnotetext{
${ }^{10}$ Folketingstidende (FT), 2018-19 meeting, Supplement A concerning L 80 (the change of Lov nr 1735 af 27/12/2018), p. 2; unless otherwise specified, all translations are by the author.
} 
nineteenth century, the Danish social imaginary had centred largely around the idea of an egalitarian, homogenous, monolinguistic nation formed by a shared identity and set of values (Mouritsen and Olsen 2013, 696). After the Second World War, this homogeneity was challenged due in particular to increasing immigration (Jønsson and Petersen 2010, 100-112). But Denmark's main political parties never embraced multiculturalism, instead maintaining the idea that immigrants had to 'integrate' into a pre-existing set of institutions and value frameworks (Mouritsen and Olsen 2013, 692; Hedetoft 2010).

From the mid-1980s, attitudes towards (in particular non-Western) migrants began to harden perceptibly (Jønsson and Petersen 2010, 115; Wren 2001). The 1990s saw the rise of the far-right Dansk Folkeparti (Danish People's Party), which had a central role in pushing the overall political agenda to the right. Policymakers increasingly emphasised the importance of assimilating non-Westerners into 'Danish culture' (Rytter 2018, 683). Since the 1990s, the concept of 'Danish values' has been utilized in a 'forward-to-thepast' move in Danish politics (Mouritsen and Olsen 2013, 693) aimed at building a contrast to a globalised world. However, what exactly these values are often remains vague (Jensen, Weibel and Vitus 2017, 65). As seen in the context of the handshake legislation, this can extend to (banal) facets of Danish (or Western) culture, which are elevated to matters of national importance.

The arguments employed in the government bill in justifying the need for the handshake requirement relied on a narrative that the 'Danish value' of greeting others respectfully was under threat. While the bill acknowledged that there could be religious grounds for refusing a handshake, the intention with the mandatory handshake was not to 'counteract worship', but to promote 'other considerations and interests'. ${ }^{11}$ According to the government, these 'other considerations and interests' were the safeguarding of 'Danish values' as expressed in the handshake as a cultural greeting. By elevating the safeguarding of a cultural practice to a legitimate aim of legislation, the legislative narrative suggested a regulatory need, implying that 'Danish values' needed safeguarding by law.

The parliamentary debate made it more explicit than the government's law proposal that this threat was deemed to emanate in particular from

${ }^{11}$ Ibid., pp. 8-9. 
Muslims. ${ }^{12}$ However, the debate did not differentiate among the few Muslims who would refuse to shake hands and the Muslim majority who would offer a handshake. The debate instead referenced the perceived problems of Islam more generally and stereotyped Muslims as a group. MPs in support of the measure argued that a handshake requirement was necessary due to a threat to 'Danish values', giving the impression that the refusal to shake hands was a widespread phenomenon. During the debate, MPs had the tendency to elevate the very specific issue of the handshake to a more fundamental one, generating an image of a cultural incompatibility that necessitated regulation.

The primary context within which the arguments invoked in favour of the handshake requirement need to be placed is the emergence of the political narrative of a threat to 'Danish values', and the growing racialization of Muslims that has accompanied it. Since the turn of the millennium, the idea of 'Danish values' being under threat has been a rhetorical driving force in Danish politics. The threat is portrayed as emanating from a combination of Islamic extremism and high levels of immigration, in particular from 'Muslim majority countries' (Hjort 2016; Rytter and Pedersen 2014). In these discourses, Islam is not discussed as a religion, but 'Muslims' tend to be defined as a group that threatens Danish society.

The perceived threat to Denmark's cultural homogeneity has led to evertighter legislation stipulating requirements for 'integration'. This legislation on integration typically emphasises the 'liberal values' of Danish society as well as the importance of 'active citizenship' (Borevi, Kriegbaum and Mouritsen 2017). This corresponds to a trend across continental Europe towards facilitating 'civic understandings of national communities' in response to the growing complexity of multicultural societies (Mouritsen 2008, 2; see also Joppke 2007 and Vertovec and Wessendorf 2010). The standards of 'civic values' introduced in the context of residence and citizenship laws are typically portrayed as non-discriminatory and inclusive, with official rhetoric stressing their 'formal equality'. However, the ideals articulated are often inherently exclusionary and more difficult to satisfy for specific groups, in particular non-Western communities.

The type of 'integration' promoted in Denmark since the turn of the millennium has predominantly focused - both implicitly and explicitly - on 'Muslims' (Jønsson and Petersen 2010, 132). 'Civic integrationism', has been

\footnotetext{
12 Ibid., pp. 7, 11-12; Folketingstidende (FT), 2018-19 meeting, Supplement F, meeting 13, 1st reading on L 80 (the change of Lov nr 1735 af 27/12/2018), 10:04; 10:21; 10:29; 11:03; 11:05; 11:11; 11:25.
} 
marked by a 'culturalisation' of political debate in which Islam and Muslims have become 'the main Other of Danish democracy' (Mouritsen and Olsen 2013, 692). In this culturalization of the debate, 'Muslim difference' has been made out as a particular problem that has to be addressed by increasingly detailed regulation appealing to 'civic values'. The result has been that Muslims are cast in opposition to the cultural majority (Rytter 2018). The 'civic integration' measures of the last two decades, along with the discourses surrounding them, have therefore increasingly shaped an idea that Muslims are a group that is unable to assimilate (Ibid).

Beyond a more generalized threat to 'Danish values', the notion of gender equality was invoked frequently in the government bill and during the parliamentary debate. The parties supporting a mandatory handshake argued that the measure was a necessary element in safeguarding gender equality in Denmark. In doing so, they invoked stereotypical presentations of gender and Islam, sidestepping the complex questions of personal autonomy, freedom of religion and the compounded vulnerabilities Muslim women might face in light of the requirement. Instead, the debate revolved exclusively around the scenario of a Muslim man refusing to shake hands with a woman. The debate that followed took a typical 'liberation' narrative, in which women have to be 'liberated' from the oppressive and discriminatory practices of Muslim men. ${ }^{13}$ The fact that the refusal to shake hands could be motivated by very different considerations than disregard for the worthiness of a particular gender, and even be understood as an act of respect towards members of the opposite sex, did not feature. The notions of gender equality in the debate remained vague and mainly served to reinforce an idea of a cultural incompatibility.

The arguments invoked in favour of the handshake requirement actively draw upon narratives surrounding 'gender equality' that have contributed to a racialization of Muslims. As in other European countries, anti-immigrant movements and parties have in Denmark instrumentalised gender equality in an anti-Muslim 'victimisation discourse' which according to political scientist Birte Siim 'contrasts gender equality in the (white) majority with the patriarchal oppression of women in the immigrant Muslim minority' (2013, 623, see also: Mulinari and Neergaard 2014). These narratives often rely on vague and paradoxical notions of gender equality (Finnsdottir and

\footnotetext{
${ }^{13}$ Folketingstidende (FT), 2018-19 meeting, Supplement F, meeting 13, 1st reading on L 80 (the change of Lov nr 1735 af 27/12/2018), 10:46.
} 
Hallgrimmsdottir 2019). Nevertheless, the powerful idea of a Nordic 'gender dilemma' has led to profound scepticism across the Danish party spectrum of immigrant groups that are deemed to be 'lagging behind' in terms of gender equality, in particular Muslims. The problem has typically been presented as unresolvable, and selected context-specific cases have been portrayed as widespread phenomena, innate to members of those groups deemed 'backward' (for a study of similar processes in Norway, see Razack 2004).

The characterization of Muslims in the legislative process as both a threat to 'Danish values' and as culturally backward in terms of gender equality thus fits a decades-long racialization of Muslims in Danish society, in which Muslims have been constructed as a group that is suspect, inferior and backward (Jensen, Weibel and Vitus 2017, 65). The political discourses and measures concerning 'Muslim Otherness' have in turn promoted an idea in the Danish social imaginary of Muslims as a group that is unable to assimilate into the cultural norms of Danish society. The legislative process behind the handshake requirement reproduced these racializing narratives and also contributed to them by rhetorically constructing a new threat emanating from 'Muslims', which needed addressing by detailed regulations.

Deconstructing the Justifications for the Handshake Requirement

At first glance, the handshake requirement could appear to be a mere 'assimilation test'. Following a narrow reading, the handshake requirement could be understood as a threshold to exclude those deemed unsuited for citizenship, while those prepared to assimilate would be granted citizenship. This would render the handshake requirement outside the aforementioned definition of racism, because individuals could choose a new group identity, and would not be limited by their innate and immutable group belonging.

But such a technical reading would fail to acknowledge the paradoxes and shortcomings in the underlying reasoning for why the handshake requirement was introduced. Even if we were to accept the argument that there was a threat to Denmark's cultural homogeneity based on a widespread refusal to shake hands, as parts of the legislative history suggest, it would be difficult to see how the handshake requirement would offer a suitable remedy: the handshake does not govern day-to-day interaction but it is a oneoff requirement in the very specific context of a citizenship ceremony. The logic behind it could of course be that it seeks to keep specific individuals, who could not possibly be assimilated, outside of the national polity. However, this is unlikely to be the case, given that a negligible number of 
individuals would refuse to shake hands after having undergone the almost ten-year, difficult and costly process of naturalisation according to the stringent Danish laws (on this see Kriegbaum, Fernandez and Brochmann 2017). The handshake requirement also does not prevent individuals from refusing handshakes after their naturalisation, nor does it affect individuals with permanent residence status. If we were to accept the official narrative of a 'threat', the shaking of hands during a citizenship ceremony would not effectively counter that threat.

It also needs to be pointed out that it would seem out of place for officials in a liberal society to seek to enforce (everyday) cultural practices by law. This is not typically the role of legislators or governments in liberal societies, and is a tool employed mainly in regard to broader political agendas. The handshake requirement thus appears more as a militant micro-regulation of cultural practices, radically enforcing an anti-Muslim agenda in the guise of defending democratic institutions and values (Invernizzi, Accetti and Zuckermann 2017).

One could of course argue that separate rules apply to the specific context of citizenship ceremonies, which after all, are about symbolically expressing allegiance to the nation. But a mandatory handshake requirement seems out of place in the context of Danish naturalisation procedures. Before the ceremony, citizenship applicants would have undergone a rigorous process for naturalisation, including comprehensive tests of Danish cultural knowledge. Even before the introduction of citizenship ceremonies, the process of naturalisation already involved the signing of an oath of allegiance. That oath is now part of the ceremony, which in itself is nothing usual (although it should be pointed out, that in the past, citizenship ceremonies were a voluntary celebration to mark the completion of the intense naturalisation process, rather than an additional legal requirement; Damsholt 2018). What is difficult to see, however, is why a mandatory handshake would be necessary as an additional legal requirement to show national allegiance, with so many steps to demonstrate that allegiance already in place.

The above, in turn, suggests that the introduction of the handshake requirement is demonstrative in nature, and in fact aimed at problematising 'Muslim culture' and portraying it as incompatible with and inferior to 'Danish values'. The handshake requirement thereby serves to construct 'Muslim difference' as a problem in the Danish social imaginary and to reinforce an idea that genuine assimilation of Muslims into Danish society is 
impossible. This is seen both in the arguments employed in favour or the bill and in the very fact that the handshake requirement was introduced in the first place. An analysis of the legislative history of the handshake requirement suggests that its aim is not so much that of targeting the few or non-existing applicants who would refuse a handshake, but to actively reinforce an imaginary insurmountable hierarchy between 'Muslim' and 'Danish' culture, making it an intentional act of racism.

\section{The Handshake Requirement Manifesting as Racism}

Even if one were to deny a racist intent on the part of the legislator, the handshake requirement still manifests as racism. The handshake requirement cannot be seen in isolation but must be assessed in view of the socio-political context in which it operates. This requires us to relate it to other policies and legislative measures as well as broader social perceptions concerning 'Muslims'.

In addition to the 'civic-integration' measures referred to above, the past few years have seen an unprecedented density of 'anti-Muslim' provisions. In 2018, Denmark followed a number of Western European countries in banning the burqa, again invoking familiar arguments of liberalism and gender-equality. ${ }^{14}$ In early 2019, the Danish Parliament passed a law banning surgical reconstruction of the hymen. ${ }^{15}$ The bill stated that the reason women undergo such surgery are archaic (Muslim) ideas of female virginity and a lack of education. ${ }^{16}$ Throughout the parliamentary debate, politicians referred to the 'medieval and oppressive views of women' still upheld by 'certain cultures'. Again, politicians argued that immigration and 'failed integration' had generated a situation in which it was necessary to legislate on the matter. This was the case despite the fact that the law proposal stated that there were no reported cases of hymenoplasty in Denmark. ${ }^{17}$ The proposed law thus singled out a seemingly 'Muslim' problem and argued that a ban was necessary in order to do away with (unenlightened) myths and misconceptions.

\footnotetext{
14 The so called "Tildækningsforbud" (Burka-ban) was added to the Danish Criminal Code through §134 c; Lov nr 717 af 08/06/2018 om ændring af straffeloven.

15 Lov nr 502 af 01/05/2019 om ændring af lov om autorisation af sundhedspersoner og om sundhedsfaglig virksomhed.

${ }^{16}$ Folketingstidende (FT), 2018-19 meeting, Supplement A concerning L 141 (the change of Lov nr 502 af 01/05/2019).

${ }^{17}$ Ibid., p. 6.
} 
The handshake requirement thus fits a pattern of micro-legislation and micro-regulation targeting 'Muslim culture'. These measures operate under the guise of protecting the rights of ethnic minority women, 'Danish values' or 'gender equality'. The combined effect of these measures, however, is the increasing portrayal of Muslims along racial lines and the imposition of heightened scrutiny and suspicion against those deemed to be part of this group (Rytter 2018, 680).

The effect of these measures is amplified by broader public conceptions of 'Muslims' and their perceived inability to fully become 'Danes'. The tight controls on naturalisation in no way means that, once citizenship has been acquired, a naturalised individual is considered 'truly Danish' from a sociocultural perspective (Sjørslev 2011). Research suggests that naturalisation of non-Western immigrants in particular is perceived with strong scepticism and widely considered to be something unusual (Midtbøen 2015). While citizenship can be formally acquired, the status of being a 'real' Dane largely remains out of reach for those with 'black hair, coloured skin, names associated with other parts of the world, and not least other religious practices and affiliations than standard Danish Protestantism' (Rytter 2010, 316). The paradox therefore emerges that despite ever-greater demands and requirements for citizenship, including the handshake requirement, no level of 'integration' or 'tests' suffices to generate a true sense of belonging for those who have successfully completed the naturalisation process.

In this social and political environment, the handshake requirement primarily manifests as anti-Muslim racism. What the handshake requirement does is reinforce an idea of the existence of a group of individuals who cannot leave their inferior, 'un-Danish' heritage behind. The combined effect of the tight regulation of 'Muslim culture' and pre-existing social stereotypes leads to a situation in which 'Muslims' are continuously required to prove their willingness and ability to assimilate, even at a cultural micro-level. Even though formally a test of assimilation, the handshake requirement actively reinforces existing stereotypes that Muslims as a group are both inferior and unable to assimilate. The heightened scrutiny that it reflects (at the legislative level) and that it leads to (in society) is what requires us to recognize it as racism. 


\section{Part II: The Limits of Anti-Discrimination Law}

\section{The Handshake Requirement as Race Discrimination}

Having established that the handshake requirement needs to be understood as drawing upon and manifesting as racism, the question that arises is in what way it can be considered race discrimination in a legal sense. 'Discrimination' is typically divided into two forms: direct and indirect discrimination. Direct discrimination refers to a situation in which like cases are not treated alike. Indirect discrimination refers to the situation in which a seemingly neutral provision has a negative impact on specific groups, despite being formally neutral.

The act of shaking hands is relevant from a legal point of view in a number of ways. But only in recent years have the legal status and political meaning of handshakes drawn wider public and academic attention. This has been a result of the ways in which the act of shaking hands has become increasingly politicized in Europe, as well as the consequences that a refusal to shake hands has had for individuals in a number of legal and administrative cases (Nieminen and Mustasaari 2019). The concept of discrimination is frequently involved in instances in which the act of shaking hands - or refusing to do so - is an issue. But as will be seen, the situations in which handshakes have been discussed from a discrimination law perspective have varied considerably, and therefore need to be distinguished.

A primary context in which handshakes have drawn attention is that of naturalisation. Many naturalisation provisions across Europe leave an administrative scope of margin for granting citizenship. Within this margin of assessment, officials can deny citizenship if there are specific counterindications. In two widely discussed cases in France ${ }^{18}$ and Switzerland ${ }^{19}$, authorities deemed the refusal to shake hands a valid ground to deny citizenship, as they considered it a sign of insufficient 'integration'. From a discrimination perspective, these cases have been discussed primarily in relation to freedom of religion, although an argument of race discrimination could potentially be made here. However, they differ from the Danish situation because they concern the exercise of executive discretion in individual cases and not general legal requirement.

\footnotetext{
18 Conseil d'État [Council of State] 2018-04-11, ECLI:FR:CECHR:2018:412462.20180411.

${ }^{19}$ The applicants initially appealed their decision, but later withdrew their appeals, making the decision of the Lausanne city council final: https://www.nzz.ch/schweiz/einbuergerung-kein-roter-pass-nach-verweigertemhandschlag-ld.1453638 (accessed 2 April 2020).
} 
Another context in which handshakes have regularly become contested is the employment context. Across Europe, there have been cases of individuals refusing a handshake on religious grounds in the work sphere, often leading to their dismissal. In 2010, the Swedish Discrimination Ombudsman won a case against the National Public Employment Agency in a case in which a Muslim man had been expelled from a job training programme based on his refusal to shake hands. ${ }^{20}$ More recently, the Discrimination Ombudsman successfully brought a case on behalf of a woman whose job interview had been cut short over a refusal to shake hands. ${ }^{21}$ In Germany, a soldier in the German army has filed a constitutional complaint procedure over his dismissal based on his refusal to shake hands with members of the opposite sex. But these cases have revolved around individual refusal to shake hands in different work contexts and are therefore different from the Danish case. ${ }^{22}$

A third context in which the act of shaking hands has recently been disputed is when a handshake is a legal requirement tied to a public office. In such instances, a handshake has a legal function comparable to that of an oath. In the German town of Eisenach, a mayor refused to shake hands with a member of the far-right party NPD during an official ceremony to swear him in as a new member of the city council. In this case, the mayor invoked her personal autonomy (religion did not play a role in this context). ${ }^{23}$ This case exemplifies a known dilemma of official roles, for which medieval jurisprudence developed the concept of the 'emperor's two bodies', referring to the 'body natural' and the 'body politic' (Kantorowitz 2016). Of the examples provided, this third case would presumably be the easiest to resolve from a legal perspective, in that the legal function of the handshake could be substituted by an oath or a comparable legal mechanism, thereby avoiding a conflict with the personal autonomy of the individual required to shake hands under current law (Schönberger 2019).

How does the Danish handshake requirement relate to these examples? There are three central ways in which the Danish handshake requirement may be seen as discriminatory: 1) in the event that an individual is denied

\footnotetext{
${ }^{20}$ Stockholms Tingsrät [Stockholm District Court], 2010-02-08, T 7324-08 (Sweden).

${ }^{21}$ Arbetsdomstolen [Labour Court] 2018-08-15, A 46/17 (Sweden).

22 The application has been filed to the Federal Constitutional Court under the file number 2 BvR 124/20, but no decision has as of yet been made in regard to its acceptance. The applicant had previously lost a case in the administrative courts: OVG Rheinland-Pfalz [Rhineland-Palatinate Higher Administrative Court], 2019-10-08, ECLI:DE:OVGRLP:2019:1008.10A11109.19.00.

23 OVG Thüringen [Thuringian Higher Administrative Court], 2019-05-03, ECLI:DE:OVGTH:2019:0503.3KO620.18.0A.
} 
citizenship based on a refusal to shake hands; 2) by demanding an individual shake hands to become citizen, thereby subjecting the applicant to scrutiny and stigmatization 3) by stigmatizing a group of individuals beyond the specific context of naturalisation, based on the very fact that the handshake requirement was introduced at all. In light of current debate, and the similarity to the aforementioned cases in France and Switzerland, the handshake requirement is likely to be discussed as discriminatory mainly in relation to the individual who is denied citizenship due to a refusal to shake hands (on religious grounds). But because the point made in this article is that the very introduction of the handshake requirement needs to be understood as racism, the focus will be on its introduction being discriminatory, and Muslims being discriminated against as a group (rather than the sub-group of applicants).

The handshake requirement needs to be understood as discrimination due to the way in which it singles out Muslims, contributes to their racialization and promotes a stigmatizing environment. The discrimination that this article aims to highlight is thus not that certain individuals are denied citizenship, but rather, that a group is declared an 'Other' and subjected to legislation that puts this group under severe scrutiny and casts them as suspect. It is because no other group than Muslims is presently being subjected to this level of suspicion that we can view the handshake requirement as discriminatory. What is of interest in the present context, therefore, is that Muslims are being treated differently because they are subjected to a series of targeted legal measures. These measures are aimed at, and/or have the consequence of, problematizing alleged Muslim cultural practices and creating a hostile, stigmatizing environment.

The present case makes it difficult to distinguish between direct and indirect discrimination. At first sight, the handshake requirement would appear to be a case of indirect discrimination, given that the wording of the requirement is neutral. However, if one accepts the argument that the introduction of the handshake requirement is intentionally demonstrative, then this would be a case of (hidden) direct discrimination. The handshake requirement might also be understood as 'harassment', as defined in Article 2(3) of the European Race Equality Directive ${ }^{24}$ as follows: '[...] when an unwanted conduct related to racial or ethnic origin takes place with the

\footnotetext{
${ }^{24}$ Council Directive 2000/43/EC of 29 June 2000 implementing the principle of equal treatment between persons irrespective of racial or ethnic origin. Official Journal L 180, p. 22.
} 
purpose or effect of violating the dignity of a person and of creating an intimidating, hostile, degrading, humiliating or offensive environment.' As the above section has demonstrated, the requirement is not neutral, but actively racializes Muslims, casts them as inferior, and contributes to a humiliating and intimidating environment for Muslims. Much of the legislative process in fact revealed that this was also the very purpose of the handshake requirement. And, operating in the context of general Islamophobia present in the country, the handshake requirement also has the effect of generating the type of environment to which Article 2(3) refers. Depending on how we assess the legislative intent, therefore, the handshake requirement may fall under different categories of discrimination. As will be seen, however, similar obstacles present themselves under all categories of discrimination when seeking to challenge the measure under antidiscrimination law.

\section{Anti-Discrimination Law and the Limits of Current Judicial Practice}

In challenging the handshake requirement by way of anti-discrimination law, some fundamental challenges present themselves. The following paragraphs briefly outline some of the obstacles of challenging more endemic forms of racism such as the handshake requirement through existing antidiscrimination law. The aim here is not so much that of offering a full doctrinal assessment of all available measures, but to point to some of the more general limitations of European Union and international human rights law in this context. These limitations apply regardless of whether we assume a case of direct discrimination, indirect discrimination or harassment.

In international law, the prohibition of race discrimination is both recognized as jus cogens and enshrined in a series of legal conventions. The International Convention on the Elimination of All Forms of Racial Discrimination (ICERD) of 1965 is an early and powerful instrument aimed at combating racism. Article 2 of ICERD commits state parties to eliminate racism in all forms. However, Article 1 (3) ICERD states that the convention is not applicable to naturalisation procedures unless they discriminate against citizens of a particular country. This would prove an obstacle in invoking ICERD in the context of the handshake requirement, although the argument could be made that the handshake requirement in fact reaches beyond the context of naturalisation.

At first glance, the European Convention of Human Rights (ECHR) would seem to offer more potential in challenging the handshake requirement. The 
European Court of Human Rights (ECtHR) has developed a case law encompassing both discrimination in aim and effect ${ }^{25}$, and it has also expanded its understanding of discrimination to include indirect discrimination ${ }^{26}$. However, the main challenge is that the anti-discrimination provision in the ECHR, Article 14, is accessory to a violation of another Convention right (such as freedom of religion). In cases in which the 'main' right in question was Article 9 (freedom of religion), the ECtHR has shown a tendency to consider only potential discrimination on grounds of religion, even where a case of race discrimination under Article 14 could potentially have been made. ${ }^{27}$ While Protocol No. 12 of the ECHR has opened up the possibility of arguing discrimination on its own, the Court remains reluctant to engage with race as a ground for discrimination (Dembour 2009).

A further challenge is that the Court still rarely considers legislative history or the context within which a measure operates. The ECtHR decision in SAS $\mathrm{v}$ France is a case in point. ${ }^{28}$ The case concerned the French law prohibiting full face veil in public. In assessing the ban, the Court did not take into account the legislative history or the ways in which the legislation manifests in society in light of French anti-Muslim public discourses (Nieminen 2019). The Court therefore failed to see how the ban was driven by a racialized discourse concerning Muslims and itself constituted a contribution to it. In fact, the Court stated that it did not consider it to be its role to 'rule on whether legislation is desirable in such matters [matters relating to the 'consolidation of stereotypes which affect certain categories of the population and of encouraging the expression of intolerance' $]^{\prime 29}$. This suggests that the Court had no interest in discussing the ways in which the legislation was part of a process of racialization.

More generally, the ECtHR also has a tendency to accept the state's reasoning as to the necessity of its legislation. Again, S.A.S. v. France serves to highlight the point. The French government in S.A.S. v. France argued that the ban was necessary in order to ensure respect for a 'minimum set of values of an open and democratic society' (para 114). The Court accepted that the ban was 'necessary in a democratic society' and for 'living together' and

\footnotetext{
${ }^{25}$ Case Relating to Certain Aspects of the Laws of Languages in Education in Belgium, European Commission of Human Rights v Belgium [1968] ECHR 3 ('Belgian Linguistics').

${ }^{26}$ For example D.H. and Others v The Czech Republic [2006] ECHR 113.

27 SAS v France [2014] ECHR 695; Grzelak v Poland [2010] ECHR 904; İzzettin Doğan and Others v Turkey [2006] ECHR 5.

${ }^{28}$ SAS v France [2014] ECHR 695.

${ }^{29}$ SAS v France [2014] ECHR 695, para 149.
} 
therefore pursued a legitimate aim. Several scholars have pointed out how the nation-state's interpretation of safeguarding 'democratic institutions' has extended far into the cultural and religious realm and how the ECtHR has shown a willingness to protect the cultural assumptions of a nation-state's ethnic majority (Macklem 2012; Nieminen 2019).

However, a fundamental difference should be pointed out between the French veil ban and the handshake requirement. The handshake is not enforced in everyday life, but is made a requirement in a singular official act. It would therefore be difficult to argue that it was 'necessary in a democratic society', unless one accepted the aforementioned and ultimately unsustainable argument that it serves to keep select individuals outside the national polity. The case should therefore be read in light of Hamidović v. Bosnia and Herzegovina ${ }^{30}$, in which the refusal to remove an Islamic skullcap in a court room was not seen as insufficient respect for a court room. The handshake requirement involves a similar act on one occasion, and may therefore, if challenged, be seen as illegitimate. It should also be pointed out that the Court has already held some of the stringent standards of Danish naturalisation procedures to be problematic from a race perspective, as seen in Biao v. Denmark. ${ }^{31}$ In light of this decision, the Court might be more willing to challenge the Danish government's reasoning than in S.A.S. v. France. ${ }^{32}$

Given its broad scope, the European 'Race Equality Directive' (RED) ${ }^{33}$ would appear to offer better protection in the present case. The RED, which in contrast to the 'Framework Equality Directive' (FED) ${ }^{34}$ extends beyond the employment context, was at the time of its adoption celebrated as an effective tool in combating racism. It also helped to put previously neglected aspects of 'race discrimination' on the map of EU law and beyond, including concepts such as indirect discrimination, 'discrimination by association'35 and 'victimless discrimination' ${ }^{36}$. This jurisprudence, in turn, has had an influence also on ECHR law, with different anti-discrimination regimes thus shaping one another and clarifying concepts of race discrimination (Barskanmaz 2019, 156).

\footnotetext{
${ }^{30}$ Hamidović v Bosnia and Herzegovina [2017] ECHR 1101.

${ }^{31}$ Biao v Denmark [2016] ECHR 455.

32 SAS v France [2014] ECHR 695.

${ }^{33}$ Council Directive 2000/43/EC.

${ }^{34}$ Council Directive 2000/78/EC of 27 November 2000 establishing a general framework for equal treatment in employment and occupation, Official Journal L 303, p. 16.

${ }^{35}$ C-83/14 CHEZ Razpredelenie Bulgaria EU:C:2015:480.

${ }^{36}$ C-54/07 Feryn EU:C:2008:397.
} 
But despite these tools to fight racism being adopted in the early 2000s, their legal potential to challenge racism has been underutilized (Möschel 2018). While the RED covers a range of 'types' of discrimination - direct discrimination (Article 2 (2) (a)) and indirect discrimination (Article 2 (2) (b)) as well as harassment (Article 2 (3)) - it has not been used widely by the courts. The RED would most likely also not be applicable in the present case, given the limitations to its scope set out in Article 3 of the Directive. In line with the ECJ's decision in Runevič-Vardyn and Wardyn, the handshake requirement would presumably be excluded from the scope of the RED because the relevant provisions would fall outside the definition of a 'public service', which in turn is the only area set out in Article 3(1) of the RED that could potentially apply in the present context. ${ }^{37}$

Regardless of whether we consider the handshake requirement to constitute direct discrimination, indirect discrimination or harassment, the legal limitations outlined above would prove serious obstacles to challenging it under international and European anti-discrimination law. In all three cases, limitations to the applicability of anti-discrimination provisions, and the narrow focus on discrimination on the basis of religion rather than race in European jurisprudence, present hurdles to challenging the handshake requirement through anti-discrimination law. In addition, direct discrimination would - in the particular context of this case - require finding a legislative or regulatory aim to target Muslims. However, the reluctance of courts to take into account legislative history and to critically examine the reasoning presented by states in justifying their measures would prove an obstacle to such a finding. Meanwhile, arguments of indirect discrimination and harassment would also be unlikely to succeed in court, due to the tendency of courts not to examine the manifestation of legal measures as racism in society.

A further, perhaps more fundamental challenge of capturing structural forms of racism is that anti-discrimination law is centred on individual instances of discrimination, which mostly require individual legal action, following a self-identification as a victim of discrimination, and often involve multiple challenges including proof of discrimination (Arnadottir 2007). While anti-discrimination provisions serve an important purpose in offering legal redress in cases of individual instances of discrimination, they are much

${ }^{37}$ C-391/09; Runevič-Vardyn and Wardyn ECLI:EU:C:2011:291. 
less potent in challenging subtle, cumulative processes of racialization and racism (Möschel, Hermanin, and Grigolo, 2016).

\section{Towards a Race-Aware understanding of the Law}

The current limitations of European and international judicial approaches to racism highlight the importance of developing a 'race-aware understanding' of the law. There are three central ways in which the law should be approached and discussed if we wish to become more fully aware of its discriminatory potential.

The first is to recognize that legal measures can be discriminatory beyond individual and immediately visible instances of discrimination. Debating law in relation to systemic discrimination and stigmatization is important if we wish to address race discrimination in a meaningful way. The type of discrimination referred to as 'harassment' in the RED might play a central role in developing this heightened understanding of structural forms of racism.

The second dimension to developing a race-aware understanding of the law is that we need to distinguish more carefully between discrimination on the grounds of religion and discrimination on the grounds of race. Separate standards should be developed in the context of race discrimination. In cases in which legislators and governments seek to justify the legitimacy of measures purportedly aiming to secure life in democratic society (as in S.A.S. $v$. France), these narratives need to be challenged, and related not merely to select instances of limitations to freedom of religion, but to the more structural processes of racialization to which they contribute.

The third point is directly related to this: in establishing whether a measure needs to be understood as racism, a context-driven approach is needed. This needs to take into account the historical background and the socio-political manifestations of different types of racism. This demands a further step away from formalistic and one-size-fits-all approaches. A handshake requirement may be racist in one context and not racist in another. This has to be carefully established, taking into account legislative intent, any racializing narratives invoked and the context in which a measure manifests itself.

More generally, legal scholars need to become race-aware, and challenge racist structures outside the narrow confines of doctrine. As a result, the very limitations of those 'higher norms' that intend to address racism need to be understood and critiqued, along with the case law that interprets them. Some 
effective tools to challenge structural racism exist, of course. But for racism in Europe to be recognized and meaningfully addressed, the narrative dimension and the real-life manifestations of law have to be more strongly recognized in light of present-day racisms. Legislators and all those working with the law need to understand its potency in contributing to processes of racialization.

\section{Conclusion}

One of the conclusions to be drawn from this article is that a discursive, deconstructive and contextual analysis of potentially racist measures is necessary if we wish to understand their implications in full. In Europe today, anti-Muslim racism often hides successfully behind anti-Muslim bigotry (Lauwers 2019). Racist measures are crafted around liberal language, with assimilation into a cultural majority allegedly never being out of reach. But the prospect of assimilation is not genuine. The narrative constructed by measures such as the handshake requirement is, in fact, that of a fundamental incompatibility between cultures that cannot be transcended by the individual.

There is some potential in how international treaties and EU Law expand the scope of protection against race discrimination. But this requires that individuals become aware of the problem in the first place. Existing provisions should be fully utilized in order to address the many forms in which racism presents itself in Europe today. This involves, in particular, moving beyond analyses of freedom of religion alone, and acknowledging race discrimination, in particular against racialized religious groups.

A further conclusion to be drawn from the example of the handshake requirement is that legal doctrine should not be the start and end point of legal scholarly engagement. Critical discourse, taking into account new theoretical debates on racism, need to be incorporated into legal scholarship. Only then can the full implications of racism in today's Europe be recognized. The entire framework of law needs to be constantly assessed and reassessed in light of the changing faces of racism. Hopefully, European legal scholars will not shy away from this challenge. 


\section{References}

\section{Official documents}

Arbetsdomstolen [Labour Court] 2018-08-15, A 46/17 (Sweden).

'Biao v Denmark' [GC] [2016] ECHR 455.

'Case "Relating to Certain Aspects of the Laws on the Use of Languages in Education in Belgium" v Belgium' [1968] ECHR 3.

Case no. C-54/07 'Centrum voor gelijkheid van kansen en voor racismbestrijding v Firma Feryn NV’ ECLI:EU:C:2008:397.

Case no. C-83/14. 'CHEZ Razpredelenie Bulgaria AD v Komisia za zashtita ot diskriminatsia' ECLI:EU:C:2015:480.

Case no. C-391/09 ‘Malgožata Runevič-Vardyn and Łukasz Paweł Wardyn v Vilniaus miesto savivaldybès administracija and Others' ECLI:EU:C:2011:291.

'D.H. and Others v The Czech Republic' [2006] ECHR 113.

Conseil d'État [Council of State]. 2018-04-11, ECLI:FR:CECHR:2018:412462.20180411.

Council Directive 2000/43/EC of 29 June 2000 implementing the principle of equal treatment between persons irrespective of racial or ethnic origin. Official Journal L 180, p. 22.

Council Directive 2000/78/EC of 27 November 2000 establishing a general framework for equal treatment in employment and occupation, Official Journal L 303, p. 16.

Folketinget. 2013. The Constitutional Act of Denmark. https://www.thedanishparliament.dk/publications/ /media/PDF/publikati oner/English/The_constitutional_act_of_denmark_2013.pdf.ashx (accessed 3 February 2020).

Folketingstidende (FT), 2018-19 meeting, Supplement A concerning L 80 (the change of Lov nr 1735 af 27/12/2018).

Folketingstidende (FT), 2018-19 meeting, Supplement F concerning L 80 (the change of Lov nr 1735 af 27/12/2018).

Folketingstidende (FT), 2018-19 meeting, Supplement A concerning L 141 (the change of Lov nr 502 af 01/05/2019).

'Grzelak v Poland' [2010] ECHR 904.

'Hamidović v Bosnia and Herzegovina' [2017] ECHR 1101.

'İzzettin Doğan and Others v Turkey' [2006] ECHR 5.

Lovtidende A. Lov nr 1735 af 27/12/2018 om ændring af lov om dansk indfødsret og lov om danskuddannelse til voksne udlændinge m.fl. [Act 
nr. 1735 of 27/12/2018 amending the Nationality Act and the Act on Danish Language Courses for Adult Foreign Nationals] (Denmark).

Lovtidende A. Lov nr 502 af 01/05/2019 om ændring af lov om autorisation af sundhedspersoner og om sundhedsfaglig virksomhed [Act nr. 502 of 01/05/2019 amending the Act on the Authorization of Healthcare Professionals and Medical Activity] (Denmark).

Lovtidende A. Lov nr 717 af 08/06/2018 om ændring af straffeloven [Act nr. 717 amending the Criminal Code] (Denmark).

OVG Rheinland-Pfalz [Rhineland-Palatinate Higher Administrative Court], 2019-10-08, ECLI:DE:OVGRLP:2019:1008.10A11109.19.00.

OVG Thüringen [Thuringian Higher Administrative Court], 2019-05-03, ECLI:DE:OVGTH:2019:0503.3KO620.18.0A

'S.A.S. v. France' [GC] [2014] ECHR 695.

Stockholms Tingsratt [Stockholm District Court], 2010-02-08, T 7324-08.

Udlændinge- og Integrationsministeriet. Bekendtgørelse nr 1767 af 27/12/2018 om kommunalbestyrelsernes afholdelse af grundlovsceremonier [Executive order nr. 1767 of 27/12/2018 on the Municipal Councils' Holding of Constitution Ceremonies].

Udlændinge- og Integrationsministeriet. Cirkulæreskrivelse nr 9779 af 14/09/2018 om naturalisation [Circular letter nr. 9779 of 14/09/2019 on Naturalisation].

\section{Literature}

Arnardóttir, Oddný Mjöll. 2007. Non-discrimination under Article 14 ECHR: the burden of proof. Scandinavian Studies in Law 51: 13-39.

Balibar, Etienne. 1991. Is there a neo-racism? In Balibar, Etienne and Wallerstein, Immanuel (eds). Race, Nation, Class - Ambiguous Identities. London: Verso.

Barskanmaz, Cengiz. 2019. Recht und Rassismus. Das menschenrechtliche Verbot der Diskriminierung aufgrund der Rasse. Berlin: Springer.

Borevi, Karin, Kriegbaum, Kristian and Mouritsen, Per. 2017. The civic turn of immigrant integration policies in the Scandinavian welfare states. Comparative Migration Studies 5 (9): 1-14.

Breeden, Aurelien. 2018. No Handshake, No Citizenship, French Court Tells Algerian Woman. The New York Times. 21 April. 
Crenshaw, Kimberle, Gotanda, Neil, Peller, Gary and Kendall, Thomas (eds.). 1995. Critical Race Theory: Key Writings that Formed the Movement. New York: New Press.

Damsholt, Tine. 2018. 'I didn't think I would be emotional until I started saying the oath' - emotionalising and ritualising citizenship. Journal of Ethnic and Migration Studies 44 (16): 2701-2716.

Delgado, Richard and Stefancic, Jean. 2017. Critical Race Theory: An Introduction. New York: New York University Press.

Dembour, Marie-Benédicte. 2009. Postcolonial Denial: Why the European Court of Human Rights Finds It So Difficult to Acknowledge Racism, in: Kamari Clarke and Mark Goodale (eds). Mirrors of Justice. Law and Power in the Post-Cold War Era. Cambridge: Cambridge University Press.

Douzinas, Costas, and Gearey, Adam. 2005. Critical Jurisprudence. Oxford: Hart Publishing.

Ersbøll, Eva. 2008. Dansk indfødsret i international og historisk belysning. Copenhagen: DJØF.

Finnsdottir, Maria and Hallgrimsdottir, Helga Kristin. 2019. Welfare State Chauvinists? Gender, Citizenship, and Anti-Democratic Politics in the Welfare State Paradise. Frontiers in Sociology (2019) (3): https://doi.org/10.3389/fsoc.2018.00046.

Frederickson, George. 2015. Racism: A short history. Princeton: Princeton University Press.

Goldberg, David Theo. 1993. Racist Culture: Philosophy and the Politics of Meaning. Oxford: Blackwell.

Gotanda, Neil. 2011. The racialization of Islam in American law. The Annals of the American Academy of Political and Social Science. 637 (1): 184-195.

Hedetoft, Ulf. 2010. Denmark versus multiculturalism. In: Vertovec, Steven and Wessendorf, Susanne (eds.). The Multiculturalism Backlash European Discourses, Policies and Practices. Oxford: Routledge.

Hertogh, Marc. 2009. What's in a Handshake? Legal Equality and Legal Consciousness in the Netherlands. Social \& Legal Studies 18 (2): 221-39. Hjort, Frederik. 2016. Who benefits? Welfare chauvinism and national stereotypes. European Union Politics 17 (1): 3-24.

Hochman, Adam. 2019. Racialization: a defense of the concept. Ethnic and Racial Studies 42 (8): 1245-1262.

Invernizzi Accetti, Carlo and Zuckerman Ian. 2017. What's Wrong with Militant Democracy? Political Studies 65 (1): 182-199. 
Jensen, Tina Gudrun, Weibel, Kristina and Vitus, Kathrine. 2017. 'There is no racism here': public discourses on racism, immigrants and integration in Denmark, Patterns of Prejudice 51 (1): 51-68.

Jønsson, Heidi Vad, and Petersen, Klaus. 2012. Denmark: A National Welfare State Meets the World, in: Brochmann, Grete and Hagelund, Anniken (eds.). Immigration Policy and the Scandinavian Welfare State 1945-2010. London: Palgrave Macmillan.

Joppke, Christian. 2007. Transformation of Citizenship: Status, Rights, Identity. Citizenship Studies 11 (1): 37-48.

Kantorowitz, Ernst. 2016 [1957]. The King's Two Bodies: A Study in Medieval Political Theology. Princeton: Princeton University Press.

Klug, Brian. 2012. Islamophobia: A concept comes of age. Ethnicities 12 (5): 665-681.

Kriegbaum Jensen, Kristian, Fernández, Christian and Brochmann, Grete. 2017. Nationhood and Scandinavian naturalization politics: varieties of the civic turn. Citizenship Studies 21 (5): 606-624.

Lauwers, Anna Sophie. 2019. Is Islamophobia (Always) Racism? Critical Philosophy of Race 7 (2): 306-322.

Macklem, Patrick. 2012. Guarding the Perimeter: Militant Democracy and Religious Freedom in Europe. Constellations Volume 19 (4): 575-590.

Meer, Nasar. 2008. The politics of voluntary and involuntary identities: are Muslims in Britain an ethnic, racial or religious minority? Patterns of prejudice 42 (1): 61-81.

Meer, Nasar. 2013. Racialization and religion: race, culture and difference in the study of antisemitism and islamophobia. Ethnic and Racial Studies 36 (3): 385-398.

Midtbøen, Arnfinn. 2015. Citizenship, integration and the quest for social cohesion: nationality reform in the Scandinavian countries. Comparative Migration Studies 3 (3): 2-15.

Mouritsen, Per and Olsen, Tore Vincents. 2013. Denmark between liberalism and nationalism. Ethnic and Racial Studies 36 (4): 691-710.

Mouritsen, Per. 2008. Political Responses to Cultural Conflict: Reflections on the Ambiguities of the Civic Turn. In: Mouritsen, Per and Jørgensen, Knud Erik (eds.). Constituting Communities - Political Solutions to Cultural Conflict. New York: Palgrave. 
Mulinari, Diana and Neergaard, Anders. 2014. We are Sweden democrats because we care for others: exploring racisms in the Swedish extreme right. European Journal of Women's Studies 21 (1): 43-56.

Möschel, Mathias. 2014. Law Lawyers and Race: Critical Race Theory from the United States to Europe. Oxford: Routledge.

Möschel, Mathias, Hermanin, Costanza and Grigolo, Michele. 2016. Fighting Discrimination in Europe - The Case for a Race-Conscious Approach. Oxford: Routledge.

Möschel, Mathias. 2018. Eighteen Years of Race Equality Directice - A Mitigated Balance. In: Belavusau, Uladzislau, and Henrard, Kristin. EU Anti-Discrimination Law beyond Gender. London: Routledge.

Nieminen, Kati. 2019. Eroding the protection against discrimination: The procedural and de-contextualized approach to S.A.S. v France. International Journal of Discrimination and the Law 19 (2): 69-88.

Nieminen, Kati, and Mustasaari, Sanna. 2019. Narratives of Belonging: Religion, the Gendered Body and Claims of Autonomy and Authenticity. In: Gozdecka, Dorota, and Macduff, Anne (eds.). Feminism, Postfeminism and Legal Theory: Beyond the Gendered Subject? London. Routledge.

O'Grady, Siobhán. 2018. After refusing a handshake, a Muslim couple was denied Swiss citizenship. The Washington Post. 18 August.

Omi, Michael, and Winant, Howard. 2015. Racial Formation in the United States: From the 1960s to the 1990s. New York, London: Routledge.

Razack, Sherene. 2004. Imperilled Muslim Women, Dangerous Muslim Men and Civilized Europeans: Legal and Social Responses to Forced Marriages. Feminist Legal Studies 12 (2): 129-174.

Rytter Mikkel. 2010. 'The Family of Denmark' and 'the Aliens': Kinship Images in Danish Integration Politics. Ethnos 75 (3): 301-322.

Rytter, Mikkel and Pedersen, Marianne Holm. 2014. A Decade of Suspicion: Islam and Muslims After 9/11. Ethnic and Racial Studies, 37 (13): 23032321.

Rytter, Mikkel. 2018. Writing Against Integration: Danish Imaginaries of Culture, Race and Belonging Ethnos. 84 (4): 678-697.

Schönberger, Sophie. 2019. Die Zwei Körper der Bürgermeisterin, VerfBlog, 2019/12/11, https://verfassungsblog.de/die-zwei-koerper-derbuergermeisterin/, DOI: https://doi.org/10.17176/20191211-180956-0. 
Siebers, Hans and Dennissen, Marjolein. 2015. Is it cultural racism? Discursive exclusion and oppression of migrants in the Netherlands. Current Sociology 63 (3): 470-489.

Siim, Birte. 2013. Gender, diversity and migration. Equality, Diversity and Inclusion: An International Journal 32 (6): 615-628.

Sjørslev, Inger. 2011. The Paradox of Integration: Excluding While Claiming to Integrate Into Danish Society. In: Olwig, Karen Fog and Paerregaard, Karsten (eds.). The Question of Integration: Immigration, Exclusion and the Danish Welfare State. Newcastle upon Tyne: Cambridge Scholars Publishing, 77-93.

Stolcke, Verena. 1995. Talking Culture: New Boundaries, New Rhetorics of Exclusion in Europe. Current Anthropology 36 (1): 1-24.

Taguieff, Pierre-André. 1990. The New Cultural Racism in France. Telos 83: 109-122.

Vertovec, Steven and Wessendorf, Susanne (eds.). 2010. The Multiculturalism Backlash - European Discourses, Policies and Practices. Oxford: Routledge.

Wren, Karen. 2001. Cultural racism: Something rotten in the state of Denmark? Social \& Cultural Geography 2 (2): 141-162.

Zakharov, Nikolay. 2015. Race, Racialization and Racism: A New Theoretical Framework. In: Zakharov, Nikolay. Race and racism in Russia. London: Palgrave Macmillan.

\section{Notes on contributor}

Anika Seemann is a Postdoctoral Research Fellow at the Max Planck Institute for Social Law and Social Policy in Munich, Germany. Her current research focuses on citizenship and social rights in the Nordic countries in both a historical and contemporary perspective. In 2019, Anika graduated with a $\mathrm{PhD}$ in legal history from the University of Cambridge. Her doctoral dissertation concerned the trials of wartime collaborators in Norway after 1945. More generally, her research interests lie at the intersection of citizenship, welfare and nationhood in Western Europe from the midnineteenth century to the present day. 